\title{
Betydelser av könsstympning hos migrerade minoriteter i Sverige
}

\author{
En feministisk våldsforskningsanalys
}

\begin{abstract}
Meanings of female genital mutilation among migrant minorities in Sweden.
A feminist violence studies analysis

The article examines meanings and attitudes to female genital mutilation among migrated minorities in Sweden. It explores the importance of family, networks, work, the role of laws and regulations, and the meaning and importance of female genital mutilation. It draws conclusions on power structures around and risk factors of female genital mutilation in relation to attitudes and attitudinal change.

The material was collected via four focus groups with 47 migrated men and women, originally from Somalia. Theoretically, the article draws on feminist institutionalism and the framework on gender regimes, and scholarship on intersectional violence, and expands the concept of violence beyond the physical, individual and intentional.

The article argues that the risk of female genital mutilation decreases considerably with migration. While some previous research has failed to consider migration as a process of attitudinal change, the article shows that attitudes do not simply migrate with migrants; they change through the processes of migration. It contributes to debates on violence from an integrationtheoretical perspective, and shows how the concepts of isolation and mobility can contribute to better explanations of attitudes and practices of female genital mutilation.
\end{abstract}

Keywords: feminist violence studies, female genital mutilation, gender, migration, minorities

ARTIKELNS SYFTE ÄR att undersöka betydelser av och attityder till könsstympning, förstått som samhälleligt och könat våld, bland migrerade män och kvinnor i Sverige utifrån ett feministiskt perspektiv på våld. Artikeln analyserar attityder, förhållningsätt och förändringsfaktorer och bidrar till kunskapsfälten om könsstympning, samhälleligt våld och könsbaserat våld.

Könsstympning är ett globalt hälsoproblem, vilket betraktas som ett brott mot de mänskliga rättigheterna och en form av våld mot kvinnor och flickor (WHO, OHCHR, UNAIDS m.fl. 2008; FN 1989). FN (2016) uppskattar att 200-400 miljoner kvinnor och flickor är drabbade samt att tre miljoner flickor årligen riskerar att utsättas för könsstympning. I Sverige uppskattar Socialstyrelsen (2015) att närmare 
38000 flickor och kvinnor kan ha varit utsatta för könsstympning. Detta ingrepp, eller övergrepp, innebär att de externa kvinnliga könsorganen amputeras eller skadas för icke-terapeutiska och icke-medicinska syften (WHO 2020). Det utförs på flickor mellan 0 och 15 år, ofta utan bedövning eller narkos, och kan få allvarliga konsekvenser för den sexuella och reproduktiva hälsan. Globalt minskar förekomsten, men genom migrationsprocesser har regionala förekomster ökat i länder där könsstympning tidigare inte förekom (Leye, Deblonde, Garcia-Anon m.fl. 2007; Mergaert, Arnaut, Exterkate m.fl. 2015). Detta har inneburit en ökad uppmärksamhet från EU och dess medlemsstater i form av rapporter, regleringar och kunskapsproduktion (EIGE 2013, 2014). Könsstympning är olagligt i många länder, men inte alla (WHO 2020). I Sverige infördes förbud mot könsstympning 1982 (SFS 1982:316) och 1998 förbjöds det även om samtycke föreligger (SFS 1998:407).

Den akademiska debatten domineras av olika hälsoperspektiv och inom denna kan något förenklat två diskurser urskiljas: den dominerande som fördömer könsstympning som ett kroppsligt övergrepp med förödande medicinska och hälsorelaterade konsekvenser, och en motdiskurs som förhåller sig kritisk till att många av de medicinska komplikationer som regelmässigt beskrivs i litteraturen saknar vetenskaplig grund (Shell-Duncan \& Hernlund 2000; Obermeyer 2003, 2005; Johnsdotter \& Essén 2016; Johnsdotter \& Mestre 2017). Motdiskursen förnekar inte att könsstympning kan leda till smärta och infektioner, eller i värsta fall döden, men framhåller att olika studier visar olika resultat och att fältet är präglat av motstridigheter. I den svenska kontexten har Birgitta Esséns, specialist i obstetrik och gynekologi och professor i internationell kvinno- och mödrahälsovård, och antropologen Sara Johnsdotters forskning varit såväl tongivande som banbrytande (se bland annat Essén \& Johnsdotter 2004a, 2004b; Johnsdotter 2002, 2010, 2018; Johnsdotter, Aregai, Carlbom m.fl. 2003). Utifrån antropologisk och sociologisk så kallad social convention theory, det vill säga teori om kulturell förändring, har Essén och Johnsdotter visat att motståndet mot könsstympning växer med tiden efter migration till länder där könsstympning inte är norm (se även Gele, Kumar, Hjelde m.fl. 2012; Gele, Johansson \& Sundby 2012; Isman, Ekeus \& Berggren 2013). En tredje position återfinns inom hedersvåldsforskningen där könsstympning har förståtts som ett sätt att kontrollera den patrilinjära arvsordningen, kvinnors sexualitet och beteende (Eldén 2002; Wikan 2004) och som ett hedersrelaterat förtryck som syftar till att skapa "rena" och avhållsamma kvinnor (Darvispour 2010; Strid \& Siddiqui 2015).

I kontrast till dessa forskningsingångar är denna artikels ingång till könsstympningsproblematiken feministisk och våldsfokuserad, vilket betyder att könsstympning förstås som ett uttryck för en specifik, patriarkal form av våld mot kvinnor och barn. Artikeln bygger förvisso vidare på tidigare forskning, men begreppsliggör könsstympning som en form av samhälleligt könat våld inom ramen för en genusregim (Walby 2009; jämför Hosken 1993[1978]). Analysen av könsstympning utifrån en feministisk förståelse av våld vidgar våldets uttryck och utsatthet bortom det fysiska, individuella och intentionella våldet. Det betyder att könsstympning förstås som en del av ett kontinuum av mäns våld mot kvinnor (Kelly 1988). Våld förstås som en ojämlikhet i 
sig, som något som alltid är könat och samverkar med andra ojämlikheter såsom ålder, nationell tillhörighet och erfarenhet av migration (Hearn 2013). Artikeln analyserar attityder till och betydelser av könsstympning som migrerade kvinnor och män i Sverige ger uttryck för, och de strukturer som förändrar respektive fastlåser dessa. Förändringsproblematiken tolkas med hjälp av begreppen inlåsning och mobilitet (Baianstovu, Strid, Särnstedt m.fl. 2019).

Genom att analysera material som samlats in via fyra fokusgrupper med sammanlagt 47 män och kvinnor som migrerat från i huvudsak Somalia till Sverige visar artikeln, i linje med tidigare forskning, att attityder till könsstympning förändras och motstånd mobiliseras som en följd av migrationsprocesser. Men det är inte enbart tidsaspekten som är avgörande för mobilisering av motstånd och attitydförändringar. För det första påverkar migrationsprocesser $i$ sig attityder och förhållningssätt: attityder flyttar inte oföränderliga med migranter, utan dessa förändras i och genom de processer och mekanismer som omgärdar migration. För det andra är motståndet och förändringen intersektionell och könad: ålder, kön och gruppens auktoriteter spelar en betydande roll. Det är i första hand kvinnors attityder som förändras och som mobiliserar motstånd. Männen i studien uttrycker en ambivalens och en osäkerhet gentemot könsstympning.

Artikeln bidrar till debatter om våld utifrån könsteoretiska perspektiv och visar hur en analys av ekonomisk, kulturell och social inlåsning och mobilitet - såsom något könat och åldersrelaterat - kan bidra till att utveckla förklaringar till och förståelser av förändrade attityder till könsstympning. Den vetenskapliga debatt som föreliggande studie skriver in sig i handlar därmed om framtida risker (och riskpopulationer) för flickor att utsättas för könsstympning, inte om praktikens hälsorisker.

\section{Feministiska våldsförståelser, genusregim, inlåsning och mobilitet}

Tre teoretiska ingångar används för att situera, förstå och analysera attityder till och praktiker av könsstympning i Sverige. Problemet situeras inom en överordnad förståelseram baserad på samhället som en genusregim (Connell 1987; Walby 2009), där kön och makt är särskilt relevanta (Hirdman 1988). Problemet förstås utifrån en feministisk våldsförståelse som vidgar våldets uttryck och utsatthet bortom det fysiska och intentionella, och förändrar förståelsen av våldets riktning (Strid \& Meier-Arendt 2020). Problemets förändring analyseras utifrån ett utvecklande av begreppsparet inlåsning och mobilitet (Baianstovu 2017).

Att förstå könsstympning utifrån en feministisk våldsförståelse innebär att förståelsen är könad, strukturell, intersektionell och maktorienterad. En feministisk våldsförståelse förstår könsstympning som en del av våldets kontinuum (Kelly 1988; Strid \& Axelsson 2020), något som både upprätthåller och upprätthålls av genusregimen (Walby 2009). Den feministiska våldsteorin vidgar förståelsen av våld mot kvinnor och barn och går bortom konventionella kriminologiska och psykologiska våldsförståelser. Detta betyder att våld definieras, förklaras och förstås utifrån ett annat perspektiv än de psykologiska och kriminologiska (se Hearn 1998 för teorier om mäns våld). 
För det första: där gängse kriminologi och psykologi ofta undersöker våld mot kvinnor och barn utifrån ett individuellt perspektiv, undersöker feministisk våldsforskning våld mot kvinnor och barn utifrån ett strukturellt perspektiv. En strukturell feministisk våldsförståelse situerar våld, såväl som till exempel migration och mänskliga relationer och processer, i en genusregim, en regim - ett system av sociala relationer och institutioner - där ojämlikheter, möjligheter och hinder, baseras på genus/kön (Walby 2009). För det andra: där kriminologisk och psykologisk våldsforskning fokuserar våld som ett fysiskt och mer eller mindre avsiktligt (brotts)fenomen, undersöker feministisk våldsforskning våld som ett fysiskt, psykiskt, emotionellt, sexuellt och ekonomiskt samhällsfenomen. Dessa förekomster av våld kan vara mer eller mindre avsiktliga eller medvetna och inte enbart syfta till att hindra, straffa eller reglera utan även till att psykologiskt kränka och trakassera (Stark 2007; Holmberg, Enander \& Lindgren 2015). Den feministiska våldsforskningen är såldes bredare och inkluderar fler våldsformer i sitt våldsbegrepp. För det tredje skiljer sig ofta å ena sidan kriminologiska och psykologiska, och å andra sidan feministiska förståelser av förövarpositionen. Medan kriminologiska och psykologiska ansatser ofta förstår förövarpositionen som relativt marginaliserad, utsatt eller socialt missanpassad, utgår en feministisk våldsförståelse från att våldet utförs av någon eller några med relativ makt och relativa privilegier. Den feministiska intersektionella våldsforskningen synliggör alltså hur förövarpositionen består av en uppsättning strukturella privilegier, exempelvis vad gäller ekonomi, arbete, språk och sociala nätverk, jämfört med offerpositionen (Walby, Armstrong \& Strid 2012; Strid, Walby \& Armstrong 2013). Detta betyder, för det fjärde, att våldets riktning skiljer sig åt mellan de olika perspektiven: i den kriminologiska och psykologiska våldsforskningen utförs våldet av de relativt maktlösa och gentemot någon med relativ makt. I den feministiska våldsforskningen är våldets riktning omvänd, från maktfull till maktlös, från relativt överordnad mot relativt underordnad. En femte viktig skillnad mellan gängse kriminologiska och psykologiska förståelser och feministiska förståelser av våld är förklaringsmodellen. Där de två tidigare förklarar våldet utifrån individuella avvikelsefaktorer såsom exempelvis psykopati, alkoholism eller missanpassning, förklarar feministisk forskning våld utifrån strukturellt normaliserade faktorer såsom ojämlikheter och makt. Våldet är normaliserat, inte en avvikelse (Lundgren, Heimer, Westerstrand m.fl. 2001; Lövkrona 2001; Lundgren 2004).

I denna artikel förstås i stället våld och våldsamma praktiker som en form av social ojämlikhet (Hearn, Strid, Humbert m.fl. 2020). Våld är här alltså en social fördelning av vem som gör vad och mot vem. Våld särskiljer människor, individuellt och strukturellt, och utgör en form av djup kroppslig diskriminering. Våld mot kvinnor och barn innebär både detaljerade brutala aktiviteter och dagliga subtila handlingar som kan leda till liv av kontroll och tvång (Stark 2007). I detta sammanhang blir begreppsparet inlåsning och mobilitet - som ett sätt att analysera våldsamma praktiker som sociala ojämlikheter - på individ-, grupp- och samhällsnivå, och i samspelet mellan dessa nivåer, centralt och ett sätt att tillämpa våldsförståelsen (Baianstovu 2017). Tillsammans betecknar de det faktum att våldsutövning tyckts öka med gränsdragning, kontroll och inom slutna grupper där samspelet med andra grupper är starkt begränsat - alltså där 
mobiliteten är låg - och näras och öka av olika former av minoritetskap (Baianstovu 2017; Baianstovu, Strid, Särnstedt m.fl 2019). Ett exempel på inlåsning är olika former av segregation genom till exempel värderingar, minoritetskap eller diskriminering på bostads- och arbetsmarknaden samt rasism. Ideologisk segregation är ett att förstå inlåsningseffekter. Här kan det till exempel handla om så självklara saker som att den egna gruppens värderingar utgör basen för gruppmedlemmarnas socialisation. Detta i sig behöver inte leda till inlåsning, men när gruppens värderingar står i stark kontrast till det omgivande samhällets värderingar skapas en gräns mellan ett "vi" och "dem" som kan fă fysiska konsekvenser. Detta gäller exempelvis när gruppens värderingar avseende flickors sexualitet inte överensstämmer med det omgivande samhällets värderingar. Inom hedersvåldsforskningen har detta uttryckts som en form av segregerande hederssocialisation (Baianstovu, Strid, Särnstedt m.fl. 2019). Social, ekonomisk och politisk rörlighet - mobilitet - däremot, urholkar våldsnormerna och minskar våldsanvändandet. Möjlighet till socialt liv, skolgång och studier, och arbete i sammanhang som skapar kontakt mellan människor är gynnsamt för sociala relationer utan våld. Med ett sådant perspektiv synliggörs att det inte är tillräckligt att undersöka huruvida studiens respondenter arbetar eller inte, det bör samtidigt undersökas huruvida ett eventuellt arbete bidrar till att skapa band mellan dem som arbetar tillsammans (Baianstovu, Strid, Särnstedt m.fl. 2019).

\section{Materialinsamling och metod}

Materialet är insamlat inom det EU-finansierade projektet Estimation of the number of girls at risk of female genital mutilation in the EU, vilket koordinerades av fil.dr Lut Mergaert (Belgien) och vars syfte var att utveckla en metod för att beräkna antalet unga flickor som riskerar att utsättas för könsstympning inom EU. Studiens kvalitativa komponent handlade om att försöka förstå om, och i så fall hur, migration påverkar eventuella attitydförändringar till könsstympning. Denna studie baserades på fokusgruppsdiskussioner med migrerade kvinnor och män över 18 år i tre länder, vilka frivilligt valde att diskutera hur deras migration hade, eller inte hade, påverkat deras beslut att låta deras döttrar omskäras eller inte omskäras. En pilotstudie genomfördes samtidigt i Sverige, Portugal och Irland $(\mathrm{N}=137)$.

I den här artikeln används materialet som samlades in i Sverige, i en mellanstor svensk stad genom 47 frågeformulär och fyra fokusgrupper med sammanlagt 32 migrerade minoritetskvinnor och 15 migrerade minoritetsmän $(\mathrm{N}=47)$. Fokusgrupperna varade mellan 150 och 180 minuter och genomfördes av författaren, ytterligare två erfarna samtalsledare varav en från en minoritetsgrupp, samt en svensk- och somalisktalande antecknare. Fokusgruppintervjuerna var semistrukturerade, det vill säga det fanns en intervjuguide med på förhand givna diskussionsteman, men deltagarnas diskussioner tilläts flyta på när det fanns intresse eller behov av avsteg från guiden. Även i tidigare svenska studier av attityder till könsstympning har det varit gruppen svensksomalier som utgjort de huvudsakliga informanterna, men i dessa studier har materialet främst insamlats via intervjuer och observationer, inte genom fokusgruppdiskussioner 
(Johnsdotter 2002, 2003, 2010, 2018; Essén \& Johnsdotter 2004a, 2004b; Wahlberg, Johnsdotter, Ekholm m.fl. 2017; Wahlberg, Essén \& Johnsdotter 2019).

Deltagargruppen identifierades och rekryterades från den i Sverige snabbast växande migrantgruppen från ett land där könsstympning är norm, Somalia. Deltagarna rekryterades med hjälp av lokala ideella föreningar. Kontakten etablerades via länsstyrelsens intersektoriella resursgrupp. Två möten med företrädare för föreningarna arrangerades där studien presenterades och frågor om anonymitet, publicering av resultat och frivilligt deltagande diskuterades. Betydelsen av etisk och respektfull behandling av det insamlade materialet underströks. Andra känsliga problem relaterade till deltagarnas utsatthet och det eventuella behovet av ytterligare stöd efter fokusgruppernas genomförande diskuterades.

En fokusgrupp är en form av kvalitativ forskning där personer i en tillfälligt sammansatt grupp tillfrågas om attityder till en produkt eller ett koncept eller ett fenomen (Kitzinger 1995). Avsikten är att, i kontrast till den individuella intervjun, skapa en dynamisk miljö där deltagarna motiverar varandras synpunkter och där diskussionen växer fram över tid och genom samspel. Fokusgrupper har visat sig vara effektiva vid utforskandet av känsliga ämnen, i arbetet med olika språkliga och kulturella miljöer, och i arbetet med svåråtkomliga grupper (Culley, Hudson \& Rapport 2007; Axelsson \& Strid 2019). Användningen av fokusgrupper kan dock ge upphov till betydande metodologiska och etiska utmaningar för forskare som arbetar med minoritetsetniska samhällen, särskilt frågor som rör språk, rekrytering och könsstympning som ett känsligt ämne (Kitzinger \& Farquhar 1999). Deltagarna var, från författarens synvinkel, förvånansvärt öppna och pratade, efter ett litet tag, med lätthet om sina tankar om och erfarenheter av könsstympning. Framförallt de äldre kvinnorna delade med sig av vad som för författaren framstår som mycket privata och känsliga erfarenheter. Lättheten, värmen och humorn som genomsyrade diskussionerna reser frågan om det kan vara så att det är ett oerfaret "vi" snarare än ett erfaret "dem" som gör frågan om könsstympning till ett känsligt ämne. En sådan diskussion, om "könsstympning som ett känsligt ämne - för vem?” vore relevant att föra i en lämplig kontext (jämför Väkiparta 2019).

Användningen av fokusgrupper som materialinsamlingsmetod i denna studie gav upphov till utmaningar när det gällde bland annat nationalitet, etnicitet, språk och kön. Även om samtalsspråket var svenska fördes en del sidodiskussioner på somaliska. Dessa språkliga utmaningar hanterades med hjälp av inspelning, noggrann lyssning av både svensk och somalitalande samt genom rekrytering av somalisktalande antecknare som närvarade under fokusgrupperna. Dessutom träffades samtalsledare, forskningsledare och författare samt en somalisk- och svensktalande tolk några veckor efter fokusgrupperna för att tillsammans lyssna igenom inspelningarna och tolka samt diskutera innehållet. Avseende kön var utmaningen att de manliga deltagarna inte bedömdes bekväma med att diskutera könsstympning med en kvinna. Därför rekryterades två manliga gruppdiskussionsledare, vilka båda hade en djup kunskap om ämnet i egenskap av sina professionella roller.

Tematisk analys användes för att identifiera och analysera särskilda teman (Braun \& Clarke 2006). För att göra detta lästes transkriptionerna av fokusgrupperna nog- 
grant och systematiskt. Kodningsprocessen här involverade först att notera, känna igen och markera specifika samtalsämnen, för att därefter systematisera dessa ämnen i överordnade teman (Boyatzis 1998).

Transkriptionerna var bitvis svårkodade, det kunde till exempel handla om huruvida vissa utsagor skulle kodas bokstavligt eller bildligt, eller om direkta motsägelser från samma respondent. Eftersom den tematiska analysen synliggör ett sorts kronologiskt utvecklande av berättelser och problem, som andra materialinsamlingsmetoder kan lämna osynliga, kunde motsägelsefulla utsagor betraktas som en utveckling av deltagarnas tankar och idéer under samtalets gång. Ett exempel på detta gäller männen, som under fokusgruppens början sade sig vara helt exkluderade från beslut om könsstympning, men som mot diskussionens slut sade sig vara involverade vad gäller att uttrycka preferenser för eller emot könsstympning, att finansiera könsstympningen samt genom sin oro över att döttrar inte skulle kunna gifta sig om de inte är skurna. Vid tillämpning av tematisk analys är det därför särskilt viktigt att vara uppmärksam på tvetydigheter, spänningar och uttalanden som uppstår, innehåll som förefaller olämpligt eller osammanhängande. Det innebar ibland kontrasterande berättelser och uttalanden mot rådande normer eller lagverk, som exempelvis när männen uttryckte oro över döttrarnas hälsa om de inte könsstympas. Vidare, då tematisk analys är särskilt användbar för att sammanföra fragment av idéer, erfarenheter och övertygelser som ofta är meningslösa när de betraktas enskilt, kunde teman som ursprungligen framstod som enstaka utsagor sammanfogas för att bilda en mer omfattande bild av gemensamma attityder och erfarenheter (Taylor \& Bogdan 1984). Slutligen synliggjorde fokusgrupperna och den tematiska analysen attityder och övertygelser som deltagarna inte var medvetna om att de hade, vilka växte fram under samtalets gång. Dessa hade inte kunnat fångas genom den enskilda och individuella intervjun. I detta avseende utgör denna artikel ett viktigt bidrag i jämförelse med tidigare omnämnda forskning, som framförallt använt intervjuer och observationer som materialinsamlingsmetod.

En mängd teman var tydliga och återkommande, till exempel hälsotemat vilket bland annat uttrycktes genom de manliga deltagarnas oro över döttrarnas hälsa om de inte könsstympas och de kvinnliga deltagarnas samtal om fysisk och psykisk smärta och kroppsliga komplikationer som följd av könsstympning. Hälsotematiken har, vilket behandlas i artikelns introduktion, diskuterats i en stor mängd tidigare forskning om könsstympning. Men fyra andra teman var minst lika framträdande. Det första var integration, som uttrycktes genom samtliga fokusgruppers differentiering mellan "hemlandet" och "här", "oss" och "dem", familjen och de sociala nätverkens homogenitet, genom arbetets och bostadsortens betydelse för den egna gruppens isolering från andra grupper. Det andra temat var institution, som bland annat uttrycktes genom deltagarnas ambivalenta position i en sorts institutionellt gränsland mellan somalisk kultur och svensk lag. Det tredje temat var identitet och mening, som uttrycktes genom samtalens fokus på vad könsstympning betyder för deltagarna, in- eller övergreppets betydelse för deltagarnas position i gruppen och samhället. Det fjärde, och sista, temat var indikatorer, ett tema som identifierar och systematiserar samtalen om risk att utsättas för könsstympning. Medan temana integration, institution samt identitet 
och mening identifierades induktivt, var det fjärde temat, indikatorer, ett på förhand bestämt tema för analysen av fokusgrupperna. Detta beror på studiens europeiska sammanhang och uppdrag (EIGE 2014).

\section{Studiens deltagare}

Av studiens 47 deltagare var 44 födda i Somalia och 45 hade somaliska föräldrar. De tre som inte var födda i Somalia var födda i Irak, Eritrea respektive Etiopien, men av dessa hade samtliga bott i Somalia. Den somaliska befolkningen i Sverige är den migrantgrupp med högst förekomst av könsstympning. Samtliga deltagare var sedan relativt länge bosatta i Sverige; en del var redan svenska medborgare eller väntade på godkännande av svenskt medborgarskap. De flesta pratade bra svenska och arbetade, genomgick en utbildning eller var föräldralediga. Några var arbetslösa. Alla deltagare bodde i en stad som är mycket etniskt segregerad. Även om deltagarnas bostadsområden är kända för sin multikulturalism finns det i dessa områden inga större influenser från europeiska kulturer.

Tre kategorier intervjuades: yngre kvinnor $(\mathrm{N}=13)$, äldre kvinnor $(\mathrm{N}=19)$ och män $(\mathrm{N}=15)$. De yngre kvinnornas medelålder var 21; de yngstas 17 och de äldstas 26 . De identifierade sig själva som praktiserande muslimer. Majoriteten av dessa kvinnor hade migrerat till Sverige efter skärningsåldern. Den genomsnittliga åldern vid ankomst var 11. Den yngsta migrerade vid 5 års ålder och den äldsta vid 17. Samtliga kom från regioner där könsstympning praktiseras och hade somaliska föräldrar; en av de yngre kvinnorna var född i Etiopien. Tre var själva föräldrar. Utbildningsnivån var generellt hög. Samtliga var svenska medborgare. De flesta deltagarna hade besökt sitt ursprungsland under de senaste tio åren.

Medelåldern hos de äldre kvinnorna var 49; den äldsta var 63 och den yngsta 39. Den genomsnittliga åldern vid migration till Sverige var 32. Den yngsta kom vid 19 års ålder och den äldsta vid 53 års ålder. 17 av de 19 kvinnorna var födda i Somalia och hade föräldrar som var födda i Somalia. En var född i Irak och en i Eritrea men båda dessa hade bott i Somalia. Fyra av de äldre kvinnorna hade även bott i andra länder innan de migrerade till Sverige. Alla utom två var mödrar. Tillsammans hade de 91 barn, i genomsnitt fem barn per kvinna. De flesta kvinnorna lönearbetade, främst som undersköterskor och personliga assistenter. De flesta hade högre utbildningsnivå än grundskola.

Medelåldern hos de manliga deltagarna var 42; för de yngsta 27 och de äldsta 63. De var alla första generationens invandrare. Den genomsnittliga åldern vid migration var 35, för den yngsta 20 och den äldsta 57. Ingen av männen hade bott i något annat land än Somalia före migration till Sverige. Alla utom en hade barn. Tillsammans hade de 68 barn, i genomsnitt sex vardera. Det äldsta barnet var 25 och de yngsta 6 månader. De var alla permanent långtidsboende i Sverige och några av dem var svenska medborgare. De flesta av dem hade någon form av utbildning i Sverige. Alla utom en arbetade eller utbildade sig. 
Tabell 1. Studiens deltagare

\begin{tabular}{lccc} 
& $\begin{array}{c}\text { Yngre migrerade } \\
\text { kvinnor }\end{array}$ & $\begin{array}{c}\text { Äldre migrerade } \\
\text { kvinnor }\end{array}$ & Migrerade män \\
\hline Antal deltagare & 13 & 19 & 15 \\
Varav födda i Somalia & 12 & 17 & 15 \\
Med somaliska föräldrar & 12 & 17 & 13 \\
Yngsta deltagarens ålder & 17 & 39 & 27 \\
Äldsta deltagarens ålder & 26 & 63 & 63 \\
Medelålder & 21 & 49 & 42 \\
Lägsta ålder vid ankomst & 5 & 19 & 20 \\
Högsta ålder vid ankomst & 17 & 53 & 57 \\
Genomsnittlig ålder vid ankomst & 11 & 32 & 35 \\
Antal deltagare med barn & 3 & 17 & 12 \\
Antal deltagare med döttrar & 0 & 16 & 10 \\
Yngsta dotterns ålder & uppgift saknas & 1 & 1 \\
Äldsta dotterns ålder & uppgift saknas & 33 & 23 \\
Antal deltagare med högre & 13 & 8 & 13 \\
utbildning än grundskola & & & \\
\hline
\end{tabular}

\section{Könsstympning som integration, institution, identitet, och praktikens indikatorer}

Detta kapitel redogör för resultaten från fokusgrupperna avseende fyra identifierade teman: 1) integration: familj och sociala nätverk; 2) institution: kunskap om och betydelse av lag-och policyramverk; 3) identitet: meningsskapande och betydelse av könsstympning för deltagarna, samt 4) indikatorer, som diskuteras i termer av vilka riskfaktorer som ökar eller minskar risken att utsättas för könsstympning. För samtliga fyra teman presenteras först resultaten från de yngre kvinnornas diskussioner, sedan de äldre kvinnornas diskussioner och därefter resultaten från männens diskussioner. Resultaten diskuteras därefter i termer av de mönster av likheter och skillnader som framträder.

\section{Integration: familj och sociala nätverk}

De yngre kvinnorna beskriver ett socialt nätverk utanför den egna etniska och religiösa gruppen. Samtliga har vuxit upp med deltagande i det svenska utbildningssystemet. Det är framförallt genom detta deltagande som de yngre kvinnornas sociala nätverk skapats och upprätthålls. De har antingen gått i den svenska grundskolan eller på gymnasiet. Några har studerat vid universitet. De har befunnit sig i etniskt och kulturellt 
blandade utbildningskontexter. De hjälper till hemma med hushållsarbete och barnpassning eller har ansvar för den egna familjens hushåll. De umgås mest med vänner med liknande eller samma etniska och religiösa bakgrund. Ingen av dem deltar i några organiserade fritidsaktiviteter, med undantag för läskurser på det lokala kulturcentret. De bor i en stad som är starkt etniskt segregerad: migrerade minoriteter och minoritetsetniciteter bor i en viss del av staden, majoritetsetniciteter i andra delar av staden.

De äldre kvinnorna saknar ett socialt nätverk utanför den egna gruppen. De bor starkt etniskt, religiöst och kulturellt segregerat. Få av dem arbetar med andra och deras fritid består av familjeliv eller av aktiviteter med den egna gruppen. Av dem som arbetar har få en kollektiv arbetsplats med kollegor; de är personliga assistenter till anhöriga eller ger vård $\mathrm{i}$ anhörigas hem. Två av de äldre kvinnorna beskriver ett arbetsliv där deras arbetsplatser utmärks av en blandning av olika nationaliteter. Deras sociala liv är starkt segregerat. De beskriver sig själva som dåligt integrerade i svenska traditioner, normer eller kultur. De flesta av dem umgås uteslutande med kvinnor och män från vad som refereras till som "hemlandet". De berättar att de inte har några, eller ytterst få, svenska vänner. Deras huvudsakliga sociala aktiviteter består av att umgås med varandra på det lokala kulturcentret. Några av dem är engagerade i, eller går ofta till, möten och sociala aktiviteter som organiseras av den lokal etniska minoritetsföreningen. De säger att det är osannolikt att deras döttrar eller söner skulle gifta sig med någon som inte kommer från samma land. De skulle inte förbjuda det, men de finner det osannolikt att det faktiskt skulle hända. De bor i en starkt segregerad stad och de bor nära varandra.

Männen beskriver ett nätverk utanför den egna etniska, religiösa och kulturella gruppen; de yngre genom utbildningssystemet och de äldre genom arbetslivet. Utanför utbildning och arbete beskriver inte männen några försök att umgås utanför den egna gruppen, men säger samtidigt att de ofta åker till centrum och går på café. Både de yngre och de äldre männen lever ett samtidigt integrerat och segregerat socialt liv på fritiden: de är aktiva i sociala nätverk inom den egna gruppen som består av kvinnor och män som migrerat från deras eget hemland eller närliggande länder. De träffar regelbundet varandra på de lokala kulturcentrumen. Ibland åker de till centrum, men de stannar ofta i den egna delen av staden på fritiden. De bor i en stad som är starkt etniskt segregerad.

Sammanfattningsvis kan sägas att de yngre kvinnornas mobilitet är hög vad gäller skola och arbete, med låg vad gäller deras fritid och hemmet. De äldre kvinnorna beskriver inlåsningseffekter såväl i hemmet, genom arbetet och på fritiden. Männen beskriver ingen direkt inlåsning, utan ger uttryck för mobilitet och rörlighet vad gäller arbete, utbildning, sociala nätverk och hemmet. Vad som dessutom tydligt framkommer är att de yngre kvinnornas relativt heterogena inlåsningsmönster och de äldre kvinnornas relativt homogena inlåsningsmönster, i kontrast till männens heterogena mobilitetsmönster, inte är valbara (se tabell 2). 
Tabell 2. Integration: inlåsning-mobilitet: jämförelse mellan yngre kvinnor, äldre kvinnor och män

\begin{tabular}{llll} 
Inlåsning-mobilitet & Yngre kvinnor & Äldre kvinnor & Män \\
\hline $\begin{array}{l}\text { Offentligt: Arbete eller skola } \\
\text { Mellan offentligt och privat: }\end{array}$ & Mobilitet & Inlåsning & Mobilitet \\
Fritid & Inlåsning & Inlåsning & Mobilitet \\
Privat: Hemmet & Inlåsning & Inlåsning & Mobilitet \\
Mönster & Heterogen & Homogen & Heterogen \\
Slutsats & Ej valbart & Ej valbart & Valbar inlåsning \\
\hline
\end{tabular}

\section{Institution: betydelser och kunskap}

Institutionernas betydelse handlar om vilket värde som tillmäts institutioner och mäts på två sätt: kunskap mäter kunskapsnivå och i vilken utsträckning personen vill eller tycker att det är värt att lägga tid på att förstå eller följa regler och regleringar; effekt mäter huruvida deltagarna (själva menar att de) förändrar sitt beteende beroende på regler, regleringar och lagar.

Bland de yngre kvinnorna är medvetenheten om det rättsliga ramverket kring könsstympning i Sverige medelhög. Samtliga är förvisso medvetna om att det är olagligt, men vet inte att detta även gäller när flickan givit sitt samtycke till det eller för svenska medborgare i länder där könsstympning är tillåtet. De vet inte att det är brottsligt att inte rapportera misstanke om planerad könsstympning.

Bland de äldre kvinnorna är medvetenheten om det rättsliga ramverket kring könsstympning i Sverige hög. De vet att lagarna gäller oavsett samtycke eller var könsstympningen utförs. De vet att de måste rapportera misstanke om könsstympning. De äldre kvinnorna säger att lagen är viktig och att den gör en skillnad: den har förhindrat planerade fall och bidragit till ökad medvetenhet om könsstympningsrelaterade frågor. De äldre kvinnorna beskriver lagen som en plattform för handling.

Männen känner till förekomsten av den svenska könsstympningslagen, men saknar kunskap om dess innehåll och om dess rättsliga konsekvenser. Några av dem vill veta om de riskerar fängelse eftersom deras döttrar är stympade och några av dem uttrycker oro över möjligheten att omskärelse av pojkar skulle kunna bli brottsligt i framtiden. Männen är mycket bestämda i sitt ifrågasättande av att lagen har någon reell betydelse eller påverkar människors handlande: om någon verkligen vill att deras dotter ska stympas kommer de att hitta ett sätt. Männen känner inte till lagstiftningen i hemlandet.

Sammanfattningsvis och jämförelsevis: varken de unga kvinnorna eller männen tillmäter det juridiska ramverket kring könsstympning någon större betydelse, utan menar i stället att om någon vill att deras dotter genomgår könsstympning så kommer de att göra det, oavsett lagen. De äldre kvinnorna däremot tillmäter det legala ramverket kring könsstympning stor betydelse (se tabell 3). 


\section{Identitet: meningsskapande och betydelse}

De yngre kvinnorna pratar ledigt om könsstympning som beskrivs som en både offentlig och privat fråga. Å ena sidan har de inte mött några särskilda reaktioner från sina vänner eller sin familj angående deltagandet i fokusgruppen och de har inte heller fått mycket information från skola eller socialarbetare om könsstympningsfrågans rättsliga status och hälsoeffekter. De upplever att informationen inte riktar sig till alla utan till unga, muslimer och somalier: "Om du är muslim eller från Somalia kommer barnmorskan, gynekologen och hälsovården att ge dig information om att det är olagligt i Sverige, inte annars." De beskriver hur de upplever fördomar och rasism. $\AA$ andra sidan anses könsstympning vara en privatsak: "Det är inte normalt att prata om könsstympning [...] det är en privat del av din kropp, inte din arm”, som någon säger. Om de däremot verkligen ville eller behövde skulle de kunna prata med sina kvinnliga vänner eller sin mamma.

De yngre flickorna beskriver betydelsen av könsstympning i Sverige och i hemlandet som delvis olika. För den andra generationens invandrarflickor, i synnerhet de som är yngre systrar, är könsstympning i princip inte ett problem: "könsstympning är inte lika relevant här som i Somalia”. Könsstympning är inte normen. Det finns, enligt dem, inga speciella konsekvenser om du är i Sverige och inte har skurits. I Somalia skulle däremot flickor som inte har stympats behöva ljuga och säga att de hade gjort det. Någon berättar att hon själv ljög och stannade hemma från skolan i en vecka för att det skulle verka som att hon återhämtade sig. Stympade flickor mobbar flickor som inte är stympade och kallar dem: "hon som flodar, om du inte är skuren svämmar [det] över när du kissar [...] du kan höra om dina vänner har klippts eller inte när de kissar, du kan stå utanför dörren och lyssna”. Könsstympning betyder renhet och betraktas enligt de yngre kvinnorna som en förutsättning för att vara en "riktig kvinna", precis som manlig omskärelse är ett sätt att skapa "riktiga män”. De menar att män bara gifter sig med flickor och kvinnor som är stympade, även i Sverige.

De äldre kvinnorna har inledningsvis svårt att prata om könsstympning, de är märkbart generade. Detta hanteras genom att samtala om könsstympning som ett kirurgiskt ingrepp, med olika medicinska och tekniska benämningar. Det är inte vanligt att prata om könsstympning. Det är möjligt, men det händer sällan. De beskriver hur detta håller på att förändras: från att ha varit ett problem som knappast nämnts har folk börjat prata om det. De pratar om bröllopsnatten som den svåraste och smärtsamma natten i sina liv, men en natt som "borde vara den lyckligaste". De benämner det nygifta paret "isen" och "isbrytaren". Meningen med könsstympning är att rena kroppen och kvinnan samt att göra könsorganen "rena och vackra"; att förvandla en flicka till en riktig kvinna. De beskriver betydelsen av könsstympning som kontroll av kvinnors sexualitet på två sätt. För det första eftersom det minskar den sexuella njutningen och då kan kvinnan antas vara trogen mot mannen. För det andra som en nödvändighet för äktenskapet; flickor måste skäras för att bevara sin oskuld före äktenskapet. De berättar att de inte visste att det fanns kvinnor som inte genomgått könsstympning förrän de flyttade till Sverige. De beskriver hur de genom möten med kvinnor från andra länder har ökat sin kunskapsbas. De säger även att det 
inte bara är de migrerande kvinnorna som har förändrats på grund av utbildning och integration utan att situationen i Somalia också har förändrats.

Män pratar inte om könsstympning; det är en kvinnofråga, säger männen. De äldre männen säger att de aldrig har pratat om könsstympning överhuvudtaget, några från den yngre generationen av män säger också detta. Många av dem har svårt att uttala själva ordet, de stakar sig fram. De menar att det pratas om könsstympning på en allmän, offentlig nivå, men inte på en privat nivå. Så är det både i Sverige och i Somalia. Könsstympning är en kvinnofråga: "pappor pratar inte om könsstympning”, säger en av dem. Betydelserna av könsstympning är många: som en bärare av traditionen, som något nödvändigt för flickors renhet och som en sexuell dygd - och dessa olika betydelser hänger ihop. Enligt traditionen är könsstympning nödvändigt eftersom det medför renhet och dygd; könsstympning fungerar enligt männen som ett sätt att upprätthålla och kontrollera flickors oskuld. Detta innebär att kvinnorna skärs, sys, öppnas och sys igen - upprepade gånger, vid samlag och efter förlossning.

Sammanfattningsvis: för de yngre kvinnorna är könsstympning både en privat och offentlig fråga, men ingenting som en pratar med sina vänner om. Könsstympning är kopplat till att vara en riktig kvinna och tillskrivs mening utifrån dess betydelse för flickors äktenskapsutsikter. Även de äldre kvinnorna anser att könsstympning är viktigt för flickors äktenskapsutsikter, men de betonar också vikten av könsstympning som en metod för att kontrollera kvinnors sexualitet. Även männen beskriver meningen med könsstympning på detta sätt, men menar samtidigt att män inte pratar om könsstympning - det är en kvinnofråga.

\section{Indikatorer och risker}

Detta avsnitt analyserar vad som upprätthåller respektive förändrar attityder till och praktiker av könsstympning. De tre gruppernas resonemang och diskussioner analyseras utifrån de faktorer som ökar respektive minskar risken för könsstympning, och deltagarnas syn på framtid och förändring.

\section{Indikatorer, risk och förändring hos yngre kvinnor}

Bland de yngre kvinnorna finns ingen oro för könsstympning. Ingen säger att de känt någon rädsla. De har aldrig tvekat att besöka hemlandet. De upplever inte att det finns något socialt tryck att skära. Men, i kontrast till detta, säger de samtidigt att de inte skulle låta sina egna flickor resa till hemlandet för att bo hos sina morföräldrar. Den första faktorn rör hälsa. Föräldrar som har fått information om hälsorisker vid skärning vill inte utsätta sina döttrar för könsstympning, menar de samstämmigt. Den andra faktorn rör religion: om kunskapen om att religionen inte kräver skärning, utan till och med förbjuder aktiva förändringar och "stympning" av människokroppen, kunde nå ut bredare så skulle könsstympning upphöra. Den tredje faktorn, som framkommer i de yngre kvinnornas berättelser, rör modernitet: de vill vara en del av det nya moderna samhället och markera avstånd mot det gamla, vilket de uppfattar som omodernt, bakåtsträvande och inneboendes av "de andra".

De två avgörande faktorerna i de yngre kvinnors diskussioner är äktenskap och 
tradition/normer. Avseende äktenskap menar de yngre kvinnorna att en tjej som inte är skuren kan uppleva svårigheter att hitta en partner att gifta sig och bilda familj med. Föräldrar låter därför skära sina döttrar eftersom de därigenom skyddar sina barns framtid. Det betyder också att det kan finnas en stark press på föräldrarna från det omgivande samhället att skära sina döttrar. Den andra faktorn är tradition och normsystem; tradition är avgörande för dem som tvingar deras döttrar att genomgå könsstympning. Detta återspeglas och understryks vid många tillfällen under hela diskussionen. Tradition och normer framhävs som de två starkaste orsakerna till att din dotter skärs.

Dessa två budskap, relaterade till hälsorisker och religion, måste levereras av personer i specifika positioner för att få genomslag. Deltagarna säger att en välutbildad person eller en person med hög social ranking kan påverka andra människors inställning till könsstympning. Människor som är utbildade i hälsa och omsorg, läkare och sjuksköterskor, är särskilt betydelsefulla i detta avseende. Två faktorer som motverkar könsstympning är givna i de yngre kvinnornas diskussion: information och utbildning. De menar att det i första hand är brist på kunskap som medför att yngre flickor skärs. Med hjälp av information och utbildning kan könsstympning stoppas, menar de yngre kvinnorna. Lagen beskrivs som irrelevant.

\section{Indikatorer, risk och förändring hos äldre kvinnor}

De äldre kvinnorna ser inte någon omedelbar risk för att deras barn eller barnbarn skulle bli skurna mot sin vilja om och när de besöker hemlandet, även om det finns en social press från systrar, bröder och grannar. De betonar dock att även detta står under förändring och hänvisar återigen till könsstympning som en gammal tradition. De säger att de inte har upplevt något socialt tryck för att skära sina döttrar i Sverige. De tror inte att detta är fallet alls, för någon, i deras grupp. De äldre kvinnorna diskuterar orsaker för och emot en mycket lång stund, och kommer fram till en mängd olika faktorer, vilka de i det närmaste formulerar som en gemensam att-göra lista för dem som vill förstå könsstympning bättre och förändra andras attityder.

Den första faktorn mot könsstympning i de äldre kvinnors berättelser är lagen: förekomsten av den svenska lagen påverkar familjens beslutet att inte skära döttrarna, när de bor i Sverige. De lyfter fram att svensk lagstiftning gör könsstympningsresan till det som de kallar hemlandet till ett brott. De äldre kvinnorna berättar att när de fick information om att svensk lag förbjuder könsstympning så fungerade den som en plattform för att söka efter mer kunskap. Deltagarna säger att kunskap om den svenska lagens innehåll ledde till att de ville förstå sin religion, och de började ställa frågor om hur en politisk lag kunde förbjuda det som föreskrivs i deras religiösa lag. I den meningen har existensen av svensk lag lett till ökad kunskap om bristen på ett religiöst krav. Den andra faktorn mot könsstympning är hälsa: dels de kunskapsbaserade hälsoeffekterna, dels de erfarna hälsoproblemen. De äldre kvinnorna menar att om du har kunskap om eller erfarenhet av de negativa hälsoeffekterna av könsstympning så kommer du inte vilja att någon annan ska behöva genomgå in- eller övergreppet. De erfarna hälsoproblemen fungerar som en avgörande faktor emot att skära eftersom, 
menar de äldre kvinnorna, deras egna erfarenheter har förändrat deras attityder till könsstympning. Den tredje faktorn mot könsstympning är mötet genom migration med andra människor: att möta kvinnor från andra länder och lära sig att alla kvinnor inte är skurna har för några av de äldre kvinnorna varit avgörande inför beslutet att inte skära deras egna döttrar.

De äldre kvinnorna diskuterar många orsaker till könsstympning och dessa kretsar kring religion, renlighet, hälsa och sexualitet. Den främsta faktorn handlar om sexualitet: de äldre kvinnorna menar att unga flickor skärs i syfte att undertrycka kvinnors sexualitet, i syfte att kontrollera kvinnors sexualitet och för att minska den sexuella lusten. Syfte med det senare är, enligt de äldre kvinnorna, att vissa samhällen och grupper anser eller tror att minskad sexlust leder till lägre risk för sex före äktenskapet. Den andra faktorn, delvis anknuten till den första, handla om ritualer och övergångsriter: att skära en ung kvinna är viktigt eftersom det markerar hennes övergång från flicka till kvinna, det markerar hennes inträde i vuxenlivet. Den tredje faktorn är att könsstympning motiveras utifrån tankar om renlighet och hygien. Den fjärde faktorn är religion: könsstympning kan vara religiöst motiverad, trots att Koranen inte nämner det, enligt de äldre kvinnorna. De två sistnämnda faktorerna, renlighet och religion, omnämns ganska ofta under diskussionen som ett möjligt sätt att försvara kvinnlig könsstympning.

Två processer och en mekanism är givna i de äldre kvinnornas diskussion: utbildning och medvetandehöjande aktiviteter samt kunskap. De äldre kvinnorna är överens om att kunskap är en central mekanism och de kopplar denna till kunskap om religion och hälsa. För det första menar de att det är viktigt att läsa om Koranen på nytt och lära sig att religionen inte kräver könsstympning. Här nämns imamerna som särskilt viktiga. Vad de säger har kraften att förändra människors attityder. För det andra menar de att ideella föreningar och icke-statliga organisationer kan ha en förändrande potential.

\section{Indikatorer, risk och förändring hos män}

Männen säger att risken för könsstympning i Sverige är minimal. Om en tjej är född i Sverige är det osannolikt att hon kommer att skäras nu. Om det inte fanns någon svensk lag mot könsstympning skulle många fler tjejer skäras i Sverige - men inte alla tjejer. Men de säger också att de tror att könsstympning kan vara nödvändigt för att flickor inte ska utsättas för hälsorisker, att det kan vara nödvändigt för att de ska bli gifta och att det är viktigt att följa normer och tradition. Den första, och enda, faktorn emot könsstympning i männens diskussion är lagen: "man måste följa regler och tradition", som någon uttrycker det. Deltagarna tror inte att en lag förhindrar könsstympning överallt, men att den gör det i Sverige. Som faktor är lagen, och rädsla för straff för brott mot den, mycket stark och en avgörande faktor för att inte skära flickor. Rädslan att hon ska berätta för myndigheterna i Sverige när hon kommer tillbaka är stark. Men om en tjej skulle skäras, skulle det ske i hemlandet, inte i Sverige eller i Norge eller Danmark.

Den första faktorn för könsstympning är äktenskap. Deltagarna berättar att soma- 
liska män - förutom dem själva - tror att tjejer behöver eller måste skäras för att kunna gifta sig eller bli gifta. De berättar att just deras söner skulle få gifta sig med en flicka som inte har skurits, men att andra fäder inte skulle tillåta detta, minoritetsgruppens sociala sammanhang skulle inte tillåta det. Samtidigt säger de att en man skulle skämmas om han gifte sig med en oklippt kvinna. Den andra faktorn för könsstympning är sexuell kontroll, vilket är relaterat till äktenskap. Samtidigt som männen menar att deras söner får gifta sig med en kvinna som inte är skuren, är de oroliga över att deras egna döttrar inte skulle bli gifta om de inte var skurna: det finns en oro för rykten om promiskuitet och ett uttalat behov av att begränsa och kontrollera döttrarnas sexualitet. Den tredje faktorn för könsstympning är hälsan: flickor som inte klipps kommer att uppleva hälsoproblem; de flesta av deltagarna trodde detta. En man sa att "om hon inte är stympad kommer det att bli katastrofala hälsoeffekter". Några av de andra deltagarna var överens om och uttryckte en genuin oro för flickornas hälsa, och kom fram till att det är bättre att skära lite grann för säkerhets skull.

Den underliggande mekanismen i männens berättelser är den sociala gemenskapen och det sociala trycket att skära döttrar, även om fadern inte vill. Männen med döttrar berättar att de upplever ett socialt tryck att få sina döttrar skurna för att förhindra promiskuitet och se till att de blir gifta. Andra beskriver hur de upplever ett socialt tryck på att vara moderna och integrerade, vilket innebär att inte skära döttrarna. Könsstympning beskrivs som något för män som inte kan anpassa sig, som inte är integrerade. Ord av religiösa ledare, myndigheter och de äldste kan vara avgörande: vad de säger värderas högt.

\section{Diskussion och slutsatser}

Detta avsnitt jämför resultaten från de fyra fokusgruppsdiskussionerna och diskuterar dem i relation till kön, feministisk våldsteori och begreppsparet inlåsning-mobilitet, samt drar slutsatser om attityder till och praktiker av könsstympning.

Familjen, i motsats till samhället, är beslutsfattare när det gäller könsstympning. Detta indikerar ett system med parallella lagar och regler utanför det svenska rättssystemet. Beslutsfattandet och den makt som följer med det kan analyseras på tre nivåer:

- Individnivå: moderns och mormoderns roller betonas; det är kvinnor som håller $i$ kniven.

- Familjenivå: pappans roll som försörjare betonas; det är män som håller i plånboken.

- Samhällsnivå: männens roll som "ägare" av äktenskapet betonas; det är män som har makten inom patriarkatet.

På privat och individuell nivå betonas att det är kvinnornas beslut att skära eller inte skära, och på samhälls- och strukturnivå är det en tradition och ett bruk som upprätthålls av män eller kvinnor på grund av vad de tror att män behöver och vill ha. Detta exemplifieras genom hur alla deltagare säger att det finns rädsla för att inga män vill 
gifta sig med oskurna flickor; män väljer bort dem. Det är moderns jobb att förbereda dottern för äktenskap och att ha hennes skuren utgör denna förberedelse. Även männen betonade moderns och mormödrarnas roll: beslutet ligger hos kvinnorna, pengarna hos männen. Det är familjens beslut att få en tjej att klippa eller inte. Fäderna har inte något att göra med könsstympning, säger de inledningsvis, även om detta uttalande kan ifrågasättas eftersom männen också berättar att fäderna 1) betalar kostnaden, 2) är oroliga för flickors hälsa om de inte stympas samt 3) ger uttryck för åsikten att oskurna flickor inte får gifta sig och att det är dåligt för flickornas hälsa att vara oskurna.

Utifrån begreppsparet inlåsning och mobilitet, vilket betecknade det faktum att olika former av våldsutövning tycks öka med tilltagande slutenhet inom grupper där samspelet med andra grupper är starkt begränsat - alltså där mobiliteten är låg - och förstärkas av olika former av minoritetskap, medan ekonomisk, kulturell, politisk och social rörlighet, å andra sidan, urholkar våldsnormer uttrycker de yngre kvinnorna en heterogen form av inlåsning och mobilitet: de har hög mobilitet genom utbildningssystemet, men hög grad av inlåsning på fritiden (se tabell 2) (Baianstovu 2017; Baianstovu, Strid, Särnstedt m.fl. 2019). Detta betyder att när mobilitet kan väljas bort, på fritiden, så väljs den bort och inlåsning blir normerande. De äldre kvinnorna ger uttryck för en homogen form av inlåsning och mobilitet: de har låg mobilitet i förhållande till arbetslivet. De har förvisso arbete, men arbetet som personlig assistent inom den egna gruppen innebär att de saknar såväl kollegor som en kollektiv arbetsplats. Deras inlåsning på fritiden är omfattande. Detta betyder att mobilitet inte är ett tillgängligt valbart alternativ: inlåsningen är norm. Männen däremot ger uttryck för en valbar och heterogen form av inlåsning och mobilitet: de har hög mobilitet genom utbildning eller arbetsliv och hög mobilitet på fritiden. Detta betyder att mobilitet kan väljas bort och är något som väljs bort. För männen blir mobiliteten valbar i deras privatliv, medan inlåsningen blir valbar och mobiliteten blir norm i deras offentliga liv. Relationen till inlåsning och mobilitet är könad, deltagarna i studien ger uttryck för en traditionell form av genusregim (Walby 2009) där såväl kvinnor och män som kvinnligt och manligt hålls isär, och där män har möjlighet att välja (Hirdman 1988). Den könsliga särorganisationen - män och kvinnor har olika roller och funktioner samt gör olika saker på olika platser - är mycket framträdande i materialet.

Att förbättra flickors och unga kvinnors utsikter att bli gifta är en huvudsaklig anledning till att skära, menar samtliga grupper. Alla tre grupperna säger på ett eller annat sätt att könsstympning är ett sätt att kontrollera kvinnors sexualitet. Stympning säkerställer att kvinnor är trofasta. De äldre kvinnorna lade till att eftersom stympning minskar sexuell njutning, betraktas flickor och kvinnor genomgått könsstympning som mindre benägna att vara otrogna. Detta innebär att kvinnorna skärs, sys, öppnas och sys igen - upprepade gånger efter förlossningen. Enligt männen är det ett socialt tryck i ursprungslandet att skära även om fadern inte skulle vilja skära sina döttrar. En man skulle skämmas om han gifte sig med en oskuren kvinna.

Utifrån en feministisk våldsförståelse, vilken vidgar våldets uttryck och utsatthet bortom det fysiska och intentionella våldet, kan könsstympning och de attityder kring 
sexualitet och äktenskap som upprätthåller praktiken förstås som en form av våld placerad inom vad Kelly (1987) kallar våldets kontinuum.

Vad som är tydligt framträder i materialet är att förövarpositionen - oavsett om vi utgår från kvinnan som håller i kniven eller män som vill försäkra sig om att dottern går att gifta bort - varken innehas av socialt missanpassade, missbrukare eller psykiskt instabila. Snarare utmärks denna position med relativ makt och relativa privilegier. Könsstympning, som en form av samhälleligt och manligt våld, utförs av någon med relativ makt gentemot någon med en relativ avsaknad av makt, både sett till ålder och kön. Detta betyder att våldets riktning skiljer sig från gängse psykologisk eller kriminologisk våldsforskning. Förövarpositionen är knuten till innehavet av en uppsättning strukturella privilegier, exempelvis vad gäller ekonomi, arbete, språk och sociala nätverk, medan offerpositionen saknar dessa privilegier (Strid, Walby \& Armstrong 2013; Strid \& Meier-Arendt 2020). Könsstympning kan inte förklaras utifrån teorier om individuella avvikelsefaktorer såsom exempelvis psykopati, alkoholism eller missanpassning, utan måste förstås i ljuset av strukturellt normaliserade faktorer såsom ojämlikheter och makt (Lövkrona 2001; Wendt Höjer 2002). Könsstympning är normaliserat, inte en avvikelse (Utredningen om kvinnofridsuppdragen 2004:54): "Fokus riktas mot alla mäns ansvar att ifrågasätta kulturella föreställningar om mäns rätt att kontrollera och utöva makt över kvinnor, och alla mäns och kvinnors ansvar för att utmana grundmurade normer för kön - hur män och kvinnor är och ska vara - blir närvarande i allas vår vardag. Avvikelseperspektiven utmanas genom att våldet varken förläggs till de socialt marginaliserade eller de kulturellt främmande eller knyts till individuella avvikelser hos gärningsman eller offer utan i stället till det vardagliga skapandet av kön.”

Migration påverkar attityder till och praktiker av könsstympning. Sociala normer, social acceptans och social status har en avgörande funktion i detta, inte minst för de yngre flickorna som vill vara en del av det moderna, männen som anser det viktigt att följa regler och normer samt de äldre kvinnorna som tillskriver mötet med andra som avgörande. Men regler och normer kan stå i konflikt, som när lagen säger en sak men den sociala gemenskapen och kulturella normer om dygd, moral, renhet och kyskhet en annan. Här framträder kunskap och tillit till gemenskapens ledare (ofta religiösa) som viktiga förändringsagenter: samtliga tre grupper tillskriver gemenskapens auktoriteter en nyckelposition i förändringsarbetet. 
Tabell 3. Sammanfattande resultatjämförelser

\begin{tabular}{llll} 
Resultatjämförelser & Yngre kvinnor & Äldre kvinnor & Män \\
\hline $\begin{array}{l}\text { Integration } \\
\text { - Privat (fritid) } \\
\text { - Offentlig (arbete eller utbildning) }\end{array}$ & $\begin{array}{l}\text { Heterogen } \\
\text { Inlåsning } \\
\text { Mobilitet }\end{array}$ & $\begin{array}{l}\text { Homogen } \\
\text { Inlåsning } \\
\text { Inlåsning }\end{array}$ & $\begin{array}{l}\text { Heterogen } \\
\text { Inlåsning } \\
\text { Mobilitet }\end{array}$ \\
$\begin{array}{l}\text { Institution } \\
\text { - Betydelse }\end{array}$ & Låg & Hög & \\
- Kunskap & Medel & Hög & Hög \\
& & & Låg \\
Identitet & & & \\
- Privat & Renhet & Renhet & Renhet \\
& Oskuld & Äktenskap & Tradition \\
& Äktenskap & Kontroll av sexualitet & Äktenskap \\
& Sexualitet & & Hälsa \\
& & & \\
Faktorer & & & Lagen \\
- Emot könsstympning & Modernitet & Mötet/migration & \\
& Hälsa & Hälsa & Äktenskap \\
- För könsstympning & Religion & Lagen & Kontroll av sexualitet \\
& Äktenskapll \\
& Tradition & Rit och ritual & kontroll \\
& Normer & Religion & Hälsa \\
& & & Medel \\
Risk & Låg & Obefintlig &
\end{tabular}

Avslutningsvis och sammanfattningsvis har artikelns analys visat vad ett feministiskt perspektiv tillför förståelsen av könsstympning som samhällelig och kulturell praktik. Här utgör artikeln ett nytt bidrag till forskningen om attityder och inställningar till könsstympning i Sverige och hur dessa påverkar förekomst. Det finns anmärkningsvärt lite kunskap och forskning om detta, även om några få banbrytande forskare såsom Sara Johnsdotter, Birgitta Essén och Anna Wahlberg sedan länge studerat migrerade gruppers attityder till könsstympning efter migration till Sverige. Den föreliggande artikelns feministiska perspektiv skiljer sig dock från deras forskningstradition och tillför kunskap om könsstympningsproblematiken som ett uttryck för samhälleligt och könat våld. I stället för att utifrån socialantropologisk teori visa hur tidsaspekten är central för attitydförändringarna har artikelns feministiska perspektiv bidragit till att synliggöra hur ålder, kön och maktposition (gruppens auktoriteter) spelar roll för attitydförändring. Det är alltså inte enbart den tid som spenderats i det nya landet som är avgörande. Det feministiska perspektiv på våld som använts i artikeln har också visat att könsstympning 
är en praktik som kan förstås inom ramen för ett kontinuum av mäns våld mot kvinnor. Förändringsproblematiken har i artikeln tolkats med hjälp av begreppsparet inlåsningmobilitet. Även detta är ett nytt bidrag till forskningen om könsstympning i Sverige. Utifrån dessa perspektiv har artikeln argumenterat för att ju fler former av och högre grad av - vald eller påtvingad - inlåsning som förekommer, desto långsammare förändras attityder till könsstympning. Dessutom är inlåsningen och dess effekter könade.

\section{Referenser}

Axelsson T.K. \& S. Strid (2019) "Minority migrant men's attitudes toward female genital mutilation. Developing strategies to engage men", Health Care for Women International. Nätpublicering. https://doi.org/10.1080/07399332.2019.1687707

Baianstovu, R.I. (2017) Heder. Hedersrelaterat våld, förtryck och socialt arbete. Lund: Studentlitteratur.

Baianstovu, R.Í., S. Strid, E. Särnstedt Gramnaes, H. Cinthio \& J.-M. Enelo (2019) Heder och sambälle. Det hedersrelaterade våldets och förtryckets uttryck och samhällets utmaningar. Örebro: Örebro University Press.

Boyatzis, R. (1998) Transforming qualitative information. Thematic analysis and code development. Thousand Oaks: Sage.

Braun, V. \& V. Clarke (2006) "Using thematic analysis in psychology", Qualitative Research in Psychology 3 (2):77-101. https://doi.org/10.1191/1478088706qp063oa

Connell, R.W. (1987) Gender and power. Society, the person, and sexual politics. Stanford: Stanford University Press.

Culley, L., N. Hudson \& F. Rapport (2007) "Using focus groups with minority ethnic communities. Researching infertility in British South Asian communities", Qualitative Health Research 17 (1):102-112. https://doi.org/10.1177/1049732306296506

Darvishpour, M. (2010) "Mannens maktförlust vid migrationen - en del i 'hedersförtryck' och konflikter inom invandrade familjer", 16-39 i M. Hansson (red.) Perspektiv på manlighet och heder. Stockholm: Gothia Förlag.

EIGE (2013) Study to map the current situation and trends of female genital mutilation in the European Union. Luxemburg: Publications Office of the EU.

EIGE (2014) Tender on collaborative study on the estimation of the number of women and girls at risk of FGM in selected EU member states (EIGE/2014/OPER/04). Vilnius: EIGE.

Eldén, Å. (2002) Heder på liv och död. Våldsamma berättelser om rykten, oskuld och heder. Uppsala: Uppsala universitet.

Essen, B. \& S. Johnsdotter (2004a) "Female genital mutilation in the West. Traditional circumcision versus genital cosmetic surgery", Acta Obstetricia et Gynecologica Scandinavica 84 (7):611-613. https://doi.org/10.1111/j.0001-6349.2004.00590.x

Essén, B. \& S. Johnsdotter (2004b) "Handläggning av könsstympade kvinnor inom den svenska vården - dags att skifta fokus från enbart underliv till hela kvinnoliv", Läkartidningen 101 (39):3003-3006.

FN (1989) Convention on the rights of the child. FN:s generalförsamlings resolution 44/25, 20 november 1989. 
FN (2016) Female genital mutilation/cutting. A global concern. New York: UNICEF.

Gele, A., B. Kumar, K. Hjelde \& J. Sundby (2012a) "Attitudes toward female circumcision among Somali immigrants in Oslo. A qualitative study", International Journal of Women's Health 4:7-17. https://doi.org/10.2147/ijwh.s27577

Gele, A., E. Johansen \& J. Sundby (2012b) "When female circumcision comes to the West. Attitudes toward the practice among Somali immigrants in Oslo", BMC Public Health 12 (697):1-10. https://doi.org/10.1186/1471-2458-12-697

Hearn, J. (1998) The violences of men. London: Sage.

Hearn, J. (2013) "The sociological significance of domestic violence", Current Sociology 61 (2):152-170. https://doi.org/10.1177/0011392112456503

Hearn, J., S. Strid, A.-L. Humbert, D. Balkmar \& M. Delauney (2020) "From gender regimes to violence regimes. Rethinking the postion of violence", Social Politics, under utgivning.

Hirdman, Y. (1988) "Genussystemet. Reflexioner kring kvinnors sociala underordning", Kvinnovetenskaplig tidskrift 3 (88):49-63.

Hosken, F.P. (1993[1978]) The Hosken report. Genital and sexual mutilation of females. Lexington: Women's International Network News.

Holmberg, C., V. Enander \& A.-L. Lindgren (2015) ”Ett litet ord betyder så mycket. Alliansregeringen, handlingsplanen och betydelseförskjutningar av begreppet mäns våld mot kvinnor", Sociologisk Forskning 52 (3):257-278.

Isman, E., C. Ekéus \& V. Berggren (2013) "Perceptions and experiences of female genital mutilation after immigration to Sweden. An explorative study", Sexual \& Reproductive Healthcare 4 (3):93-98. https://doi.org/10.1016/j.srhc.2013.04.004

Johnsdotter, S. (2002) Created by god. How Somalis in Swedish exile reassess the practice of female circumcision. Lund: Lunds universitet.

Johnsdotter, S. (2010) "Somali women in Western exile. Reassessing female circumcision in the light of Islamic teaching", Journal of Muslim Minority Affairs 23 (2):361-373. https://doi.org/10.1080/1360200032000139983

Johnsdotter, S. (2018) "The impact of migration on attitudes to female genital cutting and experiences of sexual dysfunction among migrant women with FGC", Current Sexual Health Reports 10 (1):18-24. https://doi.org/10.1007/s11930-018-0139-4

Johnsdotter, S. \& B. Essén (2016) "Cultural change after migration. Circumcision of girls in Western migrant communities", Best Practice \& Research Clinical Obstetrics \& Gynaecology 32:15-25. https://doi.org/10.1016/j.bpobgyn.2015.10.012

Johnsdotter, S. \& R.M. Mestre (2017) "'Female genital mutilation' in Europe. Public discourse versus empirical evidence", International Journal of Law, Crime and Justice 51:14-23. https://doi.org/10.1016/j.ijlcj.2017.04.005

Johnsdotter, S., R. Aregai, A. Carlbom, K. Moussa \& B. Essén (2003) "Aldrig mina döttrar". En studie om attityder till kvinnlig omskärelse bland etiopier och eritreaner i Sverige. Stockholm: Rädda Barnen.

Kelly, L. (1988) Surviving sexual violence. Minneapolis: University of Minnesota Press. Kitzinger, J. (1995) "Qualitative research. Introducing focus groups", British Medical Journal 311:299-302. https://doi.org/10.1136/bmj.311.7000.299 
Kitzinger, J. \& C. Farquhar (1999) "The analytical potential of 'sensitive moments' in focus group discussions", 156-172 i R. Barbour, \& J. Kitzinger (red.) Developing focus group research. Politics, theory, and practice. London: Sage. https://doi.org/10.4135/9781849208857.n11

Lundgren, E. (2004) Våldets normaliseringsprocess. Stockholm: Riksorganisationen för kvinno- och tjejjourer i Sverige.

Lundgren, E., G. Heimer, J. Westerstrand \& A.-K. Kalliokoski (2001) Slagen dam. Mäns våld mot kvinnor i jämställda Sverige - en omfängsundersökning. Umeå: Brottsoffermyndigheten.

Leye, E., J. Deblonde, J. Garcia-Anon, S. Johnsdotter, A. Kwateng-Kluvitse, L. WeilCuriel \& M. Temmerman (2007) "An analysis of the implementation of laws with regard to female genital mutilation in Europe", Crime, Law and Social Change 47:1-31. https://doi.org/10.1007/s10611-007-9055-7

Lövkrona, I. (2001) Mord, misshandel och sexuella övergrepp. Historiska och kulturella perspektiv på kön och våld. Lund: Nordic Academic Press.

Mergaert, L., C. Arnaut, M. Exterkate, S. O’Brien, S. Strid \& E. Leye (2015) Estimation of girls at risk of female genital mutilation in the European Union. Luxemburg: Publications Office of the EU.

Obermeyer, C.M. (2003) "The health consequences of female circumcision. Science, advocacy, and standards of evidence", Medical Anthropology Quarterly 17 (3):394412. https://doi.org/10.1525/maq.2003.17.3.394

Obermeyer, C.M. (2005) "The consequences of female circumcision for health and sexuality. An update on the evidence", Culture, Health and Sexuality 7 (5):443-461. https://doi.org/10.1080/14789940500181495

Shell-Duncan, B. \& Y. Hernlund (2000) "Female 'circumcision' in Africa. Dimensions of the practice and debates", 1-40 i B. Shell-Duncan \& Y. Hernlund (red.) Female"circumcision" in Africa. Culture, controversy, and change. London: Lynne Rienner Publishers.

SFS 1982:316. Lag med förbud mot könsstympning av kvinnor. Stockholm: Socialdepartementet.

SFS 1998:407. Lag om ändring i lagen (1982:316) med förbud mot omskärelse av kvinnor. Stockholm: Socialdepartementet.

Socialstyrelsen (2015) Flickor och kvinnor i Sverige som kan ha varit utsatta för könsstympning. En uppskattning av antalet. Stockholm: Socialstyrelsen.

Stark, E. (2007) Coercive control. The entrapment of women in personal life. Oxford: Oxford University Press.

Strid, S. \& Axelsson T.K. (2020) "Involving men. The multiple meanings of female genital mutilation in a minority migrant context", NORA - Nordic Journal of Feminist and Gender Research 28 (4), under utgivning.

Strid, S. \& D. Meier-Arendt (2020) "Våld som system. Våld, maskulinitet och förändring. Socialmedicinsk tidskrift 97 (2):235-247.

Strid, S. \& H. Siddiqui (2015) Preventing honour related violence by education and dialogue through minority NGOs. A comparative study on minority NGOs in Greece, Portugal, Sweden and the UK. Bryssel: Europeiska kommissionen. 
Strid, S., S. Walby \& J. Armstrong (2013) "Intersectionality and multiple inequalities. Visibility in British Policy on Violence Against Women”, Social Politics 20 (4):558-581. https://doi.org/10.1093/sp/jxt019

Taylor, S. \& R. Bogdan (1984) Introduction to qualitative research methods. The search for meanings. New York: Wiley and Sons.

Utredningen om kvinnofridsuppdragen (2004) Slag i luften. En utredning om myndigheter, mansvåld och makt. Betänkande av Utredningen om kvinnofridsuppdragen. SOU 2004:121. Stockholm: Fritzes.

Väkiparta, M. (2019) Young men against female genital mutilation/cutting in Somaliland. Helsinki: Unigrafia.

Wahlberg, A., S. Johnsdotter, K. Ekholm Selling, C. Källestål \& B. Essén (2017) "Factors associated with the support of pricking (female genital cutting type IV) among Somali immigrants - a cross-sectional study in Sweden", Reproductive Health 14 (92). https://doi.org/10.1186/s12978-017-0351-0

Wahlberg, A., B. Essén \& S. Johnsdotter (2019) "From sameness to difference. Swedish Somalis' post-migration perceptions of the circumcision of girls and boys", Culture, Health and Sexuality 21 (6):619-635.

https://doi.org/10.1080/13691058.2018.1502472

Walby, S. (2009) Globalisation and inequalities. London \& New York: Sage.

Walby, S., J. Armstrong \& S. Strid (2012) "Intersectionality. Multiple inequalities in social theory", Sociology 46 (2):224-240. https://doi.org/10.1177/0038038511416164

WHO, OHCHR, UNAIDS, UNDP, UNECA, UNESCO, UNFPA, UNHCR, UNICEF \& UNIFEM (2008) Eliminating female genital mutilation. An interagency statement. Genève: WHO.

WHO (2020) "Female genital mutilation", https://www.who.int/news-room/fact-sheets/detail/female-genital-mutilation (hämtningsdatum 18 juni 2020).

Wikan, U. (2004) En fråga om heder. Stockholm: Ordfront.

\title{
Författarpresentation
}

Sofia Strid är docent i genusvetenskap vid Örebro universitet. Hon forskar om kön/ genus, intersektionalitet och våld och finansieras av EU-kommissionen, Forte och Vetenskapsrådet. Bland hennes senaste publikationer återfinns, utöver de som nämns i referenslistan, även "Intersectional complexities in gender-based violence politics" (författat tillsammans med Mieke Verloo, i antologin Intersectionality in Feminist and Queer Movements, Routledge 2019).

\author{
Kontaktuppgifter författare \\ Sofia Strid \\ Enheten för genusvetenskap och sociologi \\ Örebro universitet, Fakultetsgatan 1, 70182 Örebro \\ sofia.strid@oru.se
}

